\title{
Building Consumer Trust in Cosmetic Advertisements: The Effect of Model Ethnicity and Brand Origin
}

\author{
Bomi Lee $^{1} \&$ Michelle Childs ${ }^{1}$ \\ ${ }^{1}$ Retail, Hospitality, and Tourism Management, The University of Tennessee, Knoxville, Tennessee, USA \\ Correspondence: Michelle Childs, Department of Retail, Hospitality, and Tourism Management, The University \\ of Tennessee, Knoxville, TN 37996, USA. E-mail: mlchilds@utk.edu
}

Received: March 22, $2021 \quad$ Accepted: May 8, $2021 \quad$ Online Published: May 13, 2021

doi:10.5539/ijms.v13n2p12 URL: https://doi.org/10.5539/ijms.v13n2p12

\begin{abstract}
Cosmetic brands typically seek growth opportunities and advertising in the international market. The objectives of this study are to test the differences in consumers' trust responses based on advertising factors, the moderating role of ad appeal in this relationship, and the subsequent impact on consumers' purchase behavior. Results show that Asian models are considered more trustworthy than Caucasian models in cosmetic advertisements; however, a US brand is considered more trustworthy when compared with an Asian brand. The impact of model ethnicity and brand origin on advertising trust differs based on levels of ad appeal.
\end{abstract}

Keywords: trust, ad appeal, brand origin, model ethnicity, cosmetic industry, purchase intention

\section{Introduction}

The global cosmetic industry, which includes hair care, skin care, fragrances and color cosmetics, is rapidly growing and expected to reach $\$ 805.61$ billion US by 2023 (Marketwatch, 2019). This represents a 7.14\% increase during the 2018-2023 period, which is vast when compared with other fashion industries (Marketwatch, 2019). To match global demand for cosmetic products, brands are seeking growth opportunities and advertising within international markets. Within the US market, Korean skincare routines and Korean beauty (K-beauty) have grown in interest, as more consumers seek effective alternatives as part of their beauty routines. However, despite industry trends, there is no clear understanding of effective cosmetic advertising components (e.g., brand origin, model ethnicity) that may have an impact on consumers' responses and purchase behavior related to international cosmetic brand ads. Advertising professionals often fall victim to two misconceptions: 1) consumer trust; 2) ad appeal.

A unique aspect of cosmetic advertisements is their claims to enhance favourable beauty standards (e.g., "your skin will feel softer"). However, research indicates that such claims are often bogus; in fact, only $18 \%$ of claims in advertising are considered trustworthy (Fowler, Reisenwitz, \& Carlson, 2015). Considering this staggering evidence, consumers may become sceptical toward cosmetic advertisements. Scepticism toward advertising is defined as the tendency toward disbelief in advertising claims and is a common response to advertising and the marketplace (Obermiller \& Spangenberg, 1998; Obermiller, Spangenberg, \& MacLachlan, 2005). Equipped with this knowledge, an understanding of advertising factors that contribute to consumer trust is essential, particularly as it relates to cosmetic advertisements and purchase behavior.

Moreover, an important component when investigating advertising effectiveness is ad appeal. Advertising appeal (i.e.. ad appeal), the psychological motivating power to arouse consumers' desire and action for buying (Schiffman \& Kanuk, 2007), may have an impact on the strength of consumer responses to cosmetic advertisements. However, ad appeal is often manipulated rather than measured (Couwenberg, Boksem, Dietvorst, Worm, Verbeke, \& Smidts, 2017; Rhee \& Jung, 2019; Zhenzhong \& Chen, 2020); thus, it is difficult to fully understand the variation in consumer responses to advertisements based on an ad's appeal.

Addressing the aforementioned gaps within the literature, the purposes of this experimental study are to test (i) the differences in consumers' trust responses based on advertising factors related to international cosmetic advertisements (i.e., brand origin, model ethnicity), (ii) the moderating role of ad appeal in this relationship, and (iii) the subsequent impact on consumers' purchase behavior toward cosmetic products featured in an advertisement. This study selects a US and Asian brand and tests responses by model ethnicity (Caucasian vs. 
Asian), given the popularity of K-beauty brands within the US market. The results of this study will provide preliminary data that may be helpful for both domestic and foreign (e.g., Asian) cosmetic companies targeting US consumers.

\section{Literature Review}

\subsection{Ad Scepticism and Persuasiveness}

In today's competitive global environment, advertisements often promote exaggerated claims in order to generate consumer attention and boost market share (Amyx \& Lumpkin, 2016). However, as consumers are increasing inundated with advertising claims, shoppers are becoming increasingly sceptical and distrust advertising, believing that advertisements can be manipulative or appear to have puffery, i.e., the exaggeration of the quality and truthfulness, which cannot be precisely determined (Amyx \& Lumpkin, 2016). In fact, in a recent nationwide survey of 500 consumers, less than $3 \%$ agreed that advertising claims were accurate, whereas more than three-quarters of consumers indicated that the same ads were exaggerated, which were concerning to them (Marketing Charts, 2013). Advertising scepticism or mistrust can lead to undesirable outcomes, including advertising avoidance (Baek \& Morimoto, 2012) and decreases in brand attitudes and image of the brand (Raziq, Ahmed, Ahmad, Yusaf, Sajjad, \& Waheed, 2018). Thus, an understanding of factors that contribute to generating higher levels of consumers' trust in advertisements are worthwhile, given its immediate and impactful influence on the brand.

The beauty and cosmetic industry face particular challenges with convincing consumers that their claims are true. In their content analysis of 289 cosmetic beauty ads across several well-known fashion magazines (e.g., Vogue, Glamor), researchers found that only $18 \%$ of ads had an acceptable and trustworthy claim (Fowler et al., 2015). The issue centres on the lack of regulation and stringent controls of cosmetic products (Fowler, Carson, \& Chaudhurt, 2019; Fowler et al., 2015; Newburger, 2009). The majority of beauty and cosmetic advertisements promote changes to consumers' well-being and happiness with the use of promoted products; however, evidence is insubstantial for consumer testing (Fowler et al., 2015). Thus, oftentimes, it is the responsibility of the cosmetic brand to enhance consumer trust through advertising mechanisms. While previous studies have established a general mistrust in cosmetic advertising claims (e.g., Fowler et al., 2019; Fowler et al., 2015), there is a lack of research that seeks to understand the factors that can contribute to and enhance consumers' trust based on cosmetic advertisements.

\subsection{Model Ethnicity and Brand Origin}

Skincare routines derived from Asian countries and K-beauty cosmetic products have continuously achieved an international following in recent years and are among the mainstream within the US beauty industry (Benner, 2017). Thus, brand type (i.e., country of origin) and model ethnicity in model advertising are important components for international brands.

While little research has been conducted on the effectiveness of a model's ethnicity on consumers' responses to cosmetic advertisements, the literature in source credibility help to shed light on the topic. Source credibility, i.e., the believability of the endorser or spokesperson in the advertisement (Clow, James, Kranenburg, \& Berry, 2006), is an important component in establishing effective advertising communications (Clow, James, Sisk, \& Cole, 2011). Research on source credibility in advertisements indicate that, when sources are perceived as creditable, it has an impact on attitudes, purchase behavior, and, importantly, trust (Clow et al., 2006; Lafferty \& Goldsmith, 2004; Lou \& Yuan, 2019). Recent research indicates the importance of a match or congruency between the model and product (Kim \& Kim, 2020; Lien, Chou, \& Chang, 2012; Mittelstaedt, Riesz, \& Burns, 2000; Seiler $\&$ Kucza, 2017), i.e., the perception that the endorser model fits well with the promoted product. Interestingly, in their experimental study, researchers found that US consumers reported higher levels of source credibility toward Asian-American models, which were perceived as having a significantly higher level of expertise than Caucasian models for credit cards. Given the significant rise and influence of Asian beauty products in the United States, it is likely that US consumers will identify a great fit between an Asian model and beauty products, thus generating higher trust in the advertisement claims. As such, the following hypotheses is proposed:

H1: Consumers will generate greater a) trust in the model and b) trust in the advertisement when the cosmetic ad features an Asian (vs. Caucasian) model.

Another major factor that can influence trust in advertising is country of brand origin. Stemming from construal level theory (Liberman \& Trope, 2008; Trope \& Liberman, 2010), it is likely the consumers will generate higher trust responses toward a US brand, compared with an Asian brand. This may be true because consumers make evaluative decisions based on psychological proximity, i.e., the perception that purchase decisions are either 
perceived as distant or close (Tangari, Folse, Burton, \& Pudgeon, 2010; Wiebe, Basil, \& Runté, 2017). Whether an event or action is perceived as psychologically distant is related to how consumers process viewed information (Liberman \& Trope, 2008; Trope \& Liberman, 2010). For instance, distance events or actions can be considered abstract and unpredictable; thus, consumers tend to feel greater uncertainty in decision-making (Liberman \& Trope, 2008). In the case of an Asian cosmetic brand, consumers may experience heightened uncertainty and lower levels of trust with the brand, given the greater psychological distance generated and lack of familiarity. On the other hand, psychological proximity (i.e., US brand), enhances certainty because consumers can perceive objects with greater trust (Liberman \& Trope, 2008), which encourages greater positive consumer responses (Wiebe et al., 2017). Given that US consumers are likely to generate opinions of proximity with a US brand, we hypothesize the following:

H2: Consumers will generate greater a) trust in the model and b) trust in the advertisement when the cosmetic ad features a US (vs. Asian) brand.

\subsection{Advertising Appeal}

Advertising exhibits a strong influence on consumers' product decision-making (Akbari, 2015; Verma, 2009). When an advertisement is appealing to consumers, it generates psychological motivating power that can increase consumers' desire and action for buying the advertised product (Schiffman \& Kanuk, 2007). Importantly, appealing advertisements are likely to generate positive consumer responses, thus satisfying the psychological needs of viewers (Keller, 1993). In this way, the key features of an advertisement can influence consumers' perception of the promoted items (Nguyen, 2014), namely, by enhancing consumers' attitudes toward the advertisements, generating higher levels of purchase intentions (Raza, Baker, \& Mohamad, 2019; Tran \& Nguyen, 2020). In this case, we propose that, when viewers perceive the advertisements to be appealing, it can enhance their perception of the advertisement, thus moderating and enhancing the relationship between advertising components and trust. Therefore,

H3: Ad appeal will moderate the effect of model ethnicity on a) trust in the model and b) trust in the advertisement.

H4: Ad appeal will moderate the effect of brand origin on a) trust in the model and b) trust in the advertisement.

\subsection{Purchase Intentions}

Trust is an important element that can nudge consumers toward purchase intentions (Grazioli \& Jarvenpaa, 2000; $\mathrm{Lu}, \mathrm{Fan}, \&$ Zhou, 2016). Trust in the advertising context is defined as "confidence that advertising is a reliable source of product/service information and willingness to act on the basis of information conveyed by advertising (Soh, Reid, \& Whitehill King, 2009). While researchers have utilized various dimensions of trust, common dimensions reported in the literature include integrity, reliability, benevolence, competence, confidence, likeability, and willingness to rely on (Soh et al., 2009). Thus, trust encompasses both beliefs and feelings toward the advertisement exposure, where trust is closely related to evaluations (Soh et al., 2009). When trust is generated, consumers place greater confidence in their decision-making (Soh et al., 2009) and are likely to enhance their orientations toward purchasing. Based on the above, we propose that higher trust leads to greater purchase intentions:

H5: a) Trust in the model and b) trust in the advertisement will influence purchase intentions.

Figure 1 presents the conceptual framework for this study. Overall, this study proposes that consumers' trust (i.e., trust in model and in advertisement) will vary based on the ethnicity of the model featured in the ad and the cosmetic brand's origin. Ultimately, this relationship will be enhanced when based on consumers' degree of ad appeal. Last, when consumers have gained trust, it will likely influence purchase intentions toward a cosmetic brand. 


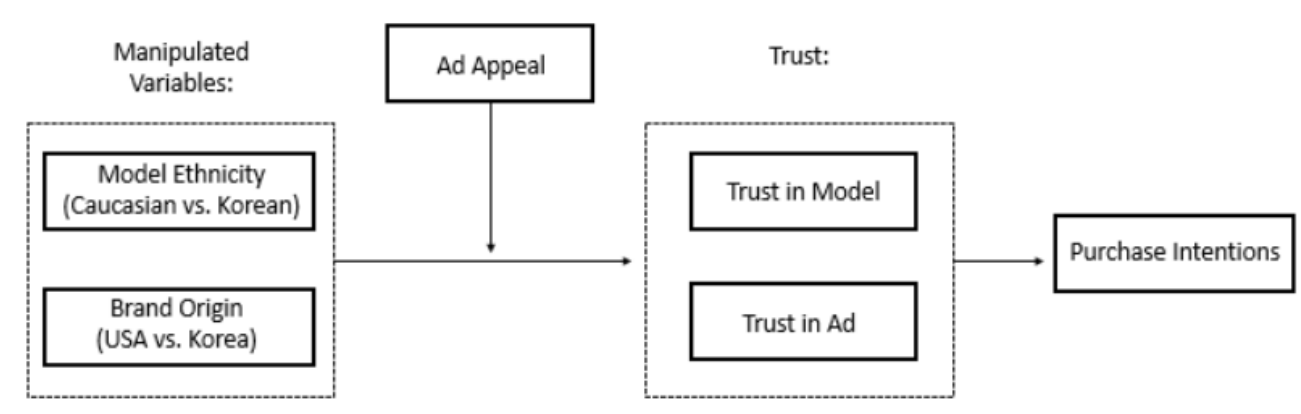

Figure 1. Conceptual model

\section{Methods}

\subsection{Stimuli Development}

A series of pre-tests were conducted to select the brand names representing the US and Asian brands. First, the authors generated a list of fictitious brand names resembling associations with the United States and Asia. Second, the generated brand names were provided to a consumer panel $(n=52)$, where respondents indicated their opinions on whether they believed the brand origin was either US or Asia. Brands were selected that elicited strong country of origin associations. Based on this, Stateside Cosmetics and Gangnam Cosmetics were selected as the US and Asian brand names, respectively. Model ethnicity (Caucasian vs. Asian) was selected from previous research (Rhee, Woo, \& Kwon, 2012). Based on the literature emphasizing cultural differences in skin tone preferences (Frisby, 2006; Xie \& Zhang, 2013), this study controlled for variations in skin tone of the model in the advertisement by including light, medium, and dark skin tones for each model ethnicity.

\subsection{Procedure and Measurement Items}

The main study employed a 2 (model ethnicity: Caucasian vs. Asian) x 2 (brand origin: US vs. Asia) experimental study. A US female online consumer panel $(n=430)$ was exposed to a cosmetic advertisement as the experimental stimuli that varied in model ethnicity and brand origin: US brand, Caucasian model $(n=108)$; US brand, Asian model $(n=103)$; Asian brand, Caucasian model $(n=120)$; and Asian brand, Asian model $(n=99)$. Females were chosen for this study because they are a main target audience for skincare and beauty products (Xie \& Zhang, 2013, See Appendix A for example stimuli.) Following exposure to the cosmetic advertisements, the participants responded to measures for trust in model (e.g., undependable/dependable), trust in ad (e.g., I think the ad is trustworthy; O'Cass, 2002), ad appeal (e.g., unappealing/appealing; Sundar \& Kalyanaraman, 2004), and purchase intentions (e.g., What is the likelihood you will purchase a product from this brand; Spears \& Singh, 2004), using 7-point Likert-type or semantic differential scales and demographic questions. Respondents' ages varied from 20 to 70 years old, with an average age of 42. Respondents were well educated, and income was normally distributed.

\section{Results}

ANOVA results indicated significant differences among model ethnicity on trust in model (Caucasian model $M=4.770$; Asian model $M=5.301 ; F=25.028 ; p=.000$ ) and trust in the advertisement (Caucasian model $M=4.624$; Asian model $M=5.137 ; F=22.992 ; p=.000$ ), thus supporting H1a and H1b. Additionally, ANOVA results indicated nonsignificant differences among brand origin on trust in model (US brand $M=5.067$; Asian brand $M=$ 4.975; $F=.712 ; p=.015)$. However, significant differences were found between brand origin on trust in advertisement (US brand $M=5.00$; Asian brand $M=4.736 ; F=5.933 ; p=.015$ ). Thus, H2a was not supported; H2b was supported. Hayes' PROCESS moderation Model 1 was used to test $\mathrm{H} 3$ and H4. While ad appeal does not moderate the effect of model ethnicity on trust in the model (Effect $=.001$; SE $=.060 ; t=.0121 ; p=.990 ; 95 \% \mathrm{CI}=$ $-.117 ; .119$ ), ad appeal moderates the effect of model ethnicity on trust in advertisements (Effect $=.169 ; \mathrm{SE}=.056$; $t=3.042 ; p=.003,95 \% \mathrm{CI}=.060 ; .279)$, with a $95 \% \mathrm{CI}$ above zero. H3a was not supported; H3b was supported. In a similar way, ad appeal does not moderate the effect of brand origin on trust in the model (Effect $=-.086$; $\mathrm{SE}=.058 ; t=-1.465 ; p=.144 ; 95 \% \mathrm{CI}=-.200, .029)$, but ad appeal does moderate the effect of brand origin on trust in the advertisement (Effect=.117; $\mathrm{SE}=.054 ; t=2.181 ; p=.030 ; 95 \% \mathrm{CI}=-.223,-.012$ ). H4a was not supported; $\mathrm{H} 4 \mathrm{~b}$ was supported. Finally, to test the effect of trust on purchase intentions, multiple regression was used. Results indicate model significance $(F=201.310 ; p=.000)$ with significant paths of trust in model $(\beta=.243$; 
$t=5.676 ; p=.000)$ and trust in advertisement $(\beta=12.248 ; t=12.248 ; p=.000)$. H5a and H5b were supported.

\section{Discussion and Implications}

In an increasingly globalized competitive environment, both US and Asian cosmetic brands are targeting a growing international audience, including US and foreign customers. On the rise, following the K-beauty trend, Asian brands are increasingly targeting US consumers. While yet to be studied, this industry phenomenon lends itself to the importance of understanding the impact of model ethnicity and brand origin on US consumers' responses to cosmetic advertisements. This study, therefore, aimed to determine effective advertising components, including model ethnicity and brand origin, which have a positive impact on trust in the model and trust in the advertisement. Given the importance of ad appeal, this study also examined the moderation effect of ad appeal between manipulated variables and trust as well as investigated the influence of trust on purchase intentions.

Regarding the influence of model ethnicity on trust, previous research within the credit card industry found that Asian-American models are perceived as possessing higher levels of expertise for US consumers in advertisements (Seiler \& Kucza, 2017). The current study expands on these findings and reveals that, within cosmetic advertisements, Asian models are perceived as more trustworthy. That is, findings indicate that, compared with Caucasian models, US consumers generate higher trust in the models and higher trust in the advertisements when Asian models are used in cosmetic advertisements. This highlights that US participants find greater trust from diverse ethnicities when compared with Caucasians. Thus, when advertising to US consumers, cosmetic brands should consider utilizing a more diverse pool of models to showcase their products in the advertisement.

Interestingly, findings indicate that a US brand generates greater trust in the advertisement for US customers than an Asian brand in cosmetic advertisements. This can be explained by construal level theory because the US brand may be perceived as having close psychological distance (Liberman \& Trope, 2008). This finding indicates that US consumers may have a preference toward US brands. Although it is possible that several US consumers may remain unaware of the rapidly growing K-beauty trend that exists in the United States, Asian brands may consider educating consumers as part of their advertising campaigns to increase consumer awareness and possibly trust.

Findings also demonstrate that the impact of model ethnicity and brand origin on advertising trust differs based on levels of ad appeal. That is, when the advertisement was considered appealing to consumers, it enhanced the relationship between model ethnicity/brand origin and trust in the advertisement. Interestingly, ad appeal did not moderate the effect of model ethnicity/brand origin on trust in the model. Perhaps, in cosmetic advertisements where claims are made to enhance favourable beauty standards, consumers may be more concerned with the overall advertising messages rather than focusing on a specific model in the advertisement. Despite mixing findings, this study still points to the importance of considering ad appeal as a moderator, providing crucial theoretical implications. Ad appeal has been used as a psychological motivating power, which increases consumers' desire for buying; however, this variable as a moderator lacks in previous research. That is, ad appeal should be considered as a measurement item rather than just a manipulated item (Couwenberg et al., 2017; Rhee \& Jung, 2019; Zhenzhong \& Chen, 2020), in enhancing the effect of advertising on researched outcomes.

Additionally, an investigation of critical factors that lead consumers toward purchasing is essential in this global competitive environment. Based on previous research (e.g., Clow et al., 2006; Grazioli \& Jarvenpaa, 2000; Lafferty \& Goldsmith, 2004; Lou \& Yuan, 2019; Lu, Fan, \& Zhou, 2016; Soh et al., 2009), this study investigated the influence of trust as an important element that may move consumers toward purchase intentions. Crucial to our understanding of cosmetic advertisements, this study indicates that trust in the model and in the advertisement are crucial factors for customers when they intend to purchase cosmetic products. As consumers' growing scepticism toward cosmetic advertisement claims continue to grow, it is essential for cosmetic brands to work toward establishing trust with consumers to move them toward purchasing behavior.

Overall, this study provides meaningful insights that may be of interest to advertising practitioners because the research is scarce on model ethnicity and brand origin within cosmetic advertising. From this study's results, cosmetic advertising practitioners can design their advertisements, thus paying careful attention to the model's ethnicity and how the origin of the brand is promoted. First, US cosmetic companies targeting US consumers should consider using Asian models for their advertisements because Caucasian models are not considered as trustworthy. In terms of brand origin, when a US brand is promoted, it generates higher levels of trust when compared with an Asian brand. This essentially means that US customers feel more comfortable with US cosmetic brands compared with foreign brands. Thus, when foreign brands target US customers, they may first 
need to make their brand familiar to the target customers, so it may not be perceived as a foreign brand. Asian brands may also consider using brand names that sound like they have origin in the United States rather than their foreign country of origin. Second, this study confirms that ad appeal and trust are imperative factors in the context of cosmetic advertising. Thus, to ensure favourable responses from US consumers, brands need to carefully curate appealing advertisements and work to generate long-term trust with their customers in order to enhance purchase intentions. These results will be helpful for both foreign (e.g., Asian) and domestic cosmetic companies targeting the US market.

Some important limitations should be noted. First, our sample was constrained to the US context. Although the United States is experiencing rapid growth of foreign beauty products, the generalizability of the findings is limited. Second, the researchers only included two ethnicities and two brand origins. Diverse ethnicity and country of origin should be included for future study; therefore, practitioners can generate more detailed information, which can be used for their cosmetic advertising, by using suitable strategies for various ethnicities in the United States and abroad. Additionally, future research should consider conducting this experimental design with participations outside the United States (e.g., Asian customers). The results might differ from those of the current study and may further shape cosmetic brand strategies.

\section{References}

Akbari, M. (2015). Different Impacts of Advertising Appeals on Advertising Attitude for High and Low Involvement Products. Global Business Review, 16(3), 478-493. https://doi.org/10.1177/0972150915569936

Amyx, D. A., \& Lumpkin, J. R. (2016). Interaction Effect of Ad Puffery and Ad Skepticism on Consumer Persuasion. Journal of Promotion Management, 22(3), 403-424. https://doi.org/10.1080/10496491.2016.1154920

Baek, T. H., \& Morimoto, M. (2012). Stay Away from Me. Journal of Advertising, 41(1), 59-76. https://doi.org/10.2753/JOA0091-3367410105

Benner, J. (2017). Snail Mucus Isn't the Only Reason Korean Beauty Is Big Right Now. Retrieved from http://www.apartmenttherapy.com/why-korean-beauty-products-are-everywhere-right-now-241448

Clow, K. E., James, K. E., Kranenburg, K. E., \& Berry, C. T. (2006). The Relationship of the Visual Element of an Advertisement to Service Quality Expectations and Source Credibility. Journal of Services Marketing, 20(6), 404-414. https://doi.org/10.1108/08876040610691293

Clow, K. E., James, K. E., Sisk, S. E., \& Cole, H. S. (2011). Source Credibility, Visual Strategy and the Model in Print Advertisements. Journal of Marketing Development and Competitiveness, 5(3), 24-31.

Couwenberg, L. E., Boksem, M. A., Dietvorst, R. C., Worm, L., Verbeke, W. J., \& Smidts, A. (2017). Neural Responses to Functional and Experiential Ad Appeals: Explaining Ad Effectiveness. International Journal of Research in Marketing, 34(2), 355-366. https://doi.org/10.1016/j.ijresmar.2016.10.005

Fowler, J. G., Carlson, L., \& Chaudhuri, H. R. (2019). Assessing Scientific Claims in Print Ads that Promote Cosmetics: How Consumers Perceive Cosmeceutical Claims. Journal of Advertising Research, 59(4), 466-482. https://doi.org/10.2501/JAR-2018-048

Fowler, J. G., Reisenwitz, T. H., \& Carlson, L. (2015). Deception in Cosmetics Advertising: Examining Cosmetics Advertising Claims in Fashion Magazine Ads. Journal of Global Fashion Marketing, 6(3), 194-206. https://doi.org/10.1080/20932685.2015.1032319

Frisby, C. M. (2006). Shades of Beauty: Examining the Relationship of Skin Color to Perceptions of Physical Attractiveness. Facial Plastic Surgery, 22(3), 175-179. https://doi.org/10.1055/s-2006-950174

Grazioli, S., \& Jarvenpaa, S. L. (2000). Perils of Internet Fraud: An Empirical Investigation of Deception and Trust with Experienced Internet Consumers. IEEE Transactions on Systems, Man, and Cybernetics-Part A: Systems and Humans, 30(4), 395-410. https://doi.org/10.1109/3468.852434

Keller, K. L. (1993). Memory Retrieval Factors and Advertising Effectiveness (pp. 11-48). Hillsdale, NJ: Lawrence Erlbaum Associates.

Kim, D. Y., \& Kim, H. Y. (2020). Influencer Advertising on Social Media: The Multiple Inference Model on Influencer-Product Congruence and Sponsorship Disclosure. Journal of Business Research, 130, 405-415. https://doi.org/10.1016/j.jbusres.2020.02.020

Lafferty, B. A., \& Goldsmith, R. E. (2004). How Influential are Corporate Credibility and Endorser 
Attractiveness when Innovators React to Advertisements for a New High-Technology Product? Corporate Reputation Review, 7(1), 24-36. https://doi.org/10.1057/palgrave.crr.1540209

Liberman, N., \& Trope, Y. (2008). The Psychology of Transcending the Here and Now. Science, 322(5905), 1201-1205. https://doi.org/10.1126/science.1161958

Lien, N. H., Chou, H. Y., \& Chang, C. H. (2012). Advertising Effectiveness and the Match-Up Hypothesis: Examining Spokesperson Sex, Attractiveness Type, and Product Image. Journal of Current Issues \& Research in Advertising, 33(2), 282-300. https://doi.org/10.1080/10641734.2012.700809

Lou, C., \& Yuan, S. (2019). Influencer Marketing: How Message Value and Credibility Affect Consumer Trust of Branded Content on Social Media. Journal of Interactive Advertising, 19(1), 58-73. https://doi.org/10.1080/15252019.2018.1533501

Lu, B., Fan, W., \& Zhou, M. (2016). Social Presence, Trust, and Social Commerce Purchase Intention: An Empirical Research. Computers in Human Behavior, 56, 225-237. https://doi.org/10.1016/j.chb.2015.11.057

Marketing Charts. (2013). Consumer Say They Don't Trust Claims Made in Ads. Retrieved from https://www.marketingcharts.com/brand-related/brand-metrics-25893

Market Watch. (2019). Cosmetic Product Market 2019 Global Industry Trends. Retrieved from https://www.marketwatch.com/press-release/cosmetics-products-market-2019-globalindustry-trends-share-s ize-demand-growth-opportunities-industry-revenue-futureandbusiness-analysis-by-forecast-2023-2019-07-1 1

Mittelstaedt, J. D., Riesz, P. C., \& Burns, W. J. (2000). Why are Endorsements Effective? Sorting among Theories of Product and Endorser Effects. Journal of Current Issues \& Research in Advertising, 22(1), 55-65. https://doi.org/10.1080/10641734.2000.10505101

Newburger, A. E. (2009). Cosmeceuticals: Myths and Misconceptions. Clinics in Dermatology, 27(5), 446-452. https://doi.org/10.1016/j.clindermatol.2009.05.008

Nguyen, H. (2014). Advertising Appeals and Cultural Values in Social Media Commercials in UK, Brazil, and India: Case Study of Nokia and Samsung. International Journal of Social, Education, Economics and Management Engineering, 8(8), 2369-2377. https://doi.org/10.5281/zenodo.1337363

O'Cass, A. (2002). Political Advertising Believability and Information Source Value during Elections. Journal of Advertising, 31(1), 63-74. https://doi.org/10.1080/00913367.2002.10673661

Obermiller, C., \& Spangenberg, E. R. (1998). Development of a Scale to Measure Consumer Skepticism toward Advertising. Journal of Consumer Psychology, 7(2), 159-186. https://doi.org/10.1207/s15327663jcp0702_03

Obermiller, C., Spangenberg, E., \& MacLachlan, D. L. (2005). Ad Skepticism: The Consequences of Disbelief. Journal of Advertising, 34(3), 7-17. https://doi.org/10.1080/00913367.2005.10639199

Raza, H. S., Baker, H. A., \& Mohamad, B. (2019). The Effects of Advertising Appeals on Consumers' Behavioural Intention towards Global Brands: The Mediating Role of Attitude and the Moderating Role of Uncertainty Avoidance. Journal of Islamic Marketing, 11(2), 440-460. https://doi.org/10.1108/JIMA-11-2017-0134

Raziq, M. M., Ahmed, Q. M., Ahmad, M., Yusaf, S., Sajjad, A., \& Waheed, S. (2018). Advertising Skepticism, Need for Cognition and Consumers' Attitudes. Marketing Intelligence \& Planning, 36(6), 678-693. https://doi.org/10.1108/MIP-11-2017-0273

Rhee, E. S., \& Jung, W. S. (2019). Brand Familiarity as a Moderating Factor in the Ad and Brand Attitude Relationship and Advertising Appeals. Journal of Marketing Communications, 25(6), 571-585. https://doi.org/10.1080/13527266.2018.1461124

Rhee, S. C., Woo, K. S., \& Kwon, B. (2012). Biometric Study of Eyelid Shape and Dimensions of Different Races with References to Beauty. Aesthetic Plastic Surgery, 36(5), 1236-1245. https://doi.org/10.1007/s00266-012-9937-7

Schiffman, L. G., \& Kanuk, L. L. (2007). Consumer Behavior. Pearson: Education International Press.

Seiler, R., \& Kucza, G. (2017). Source Credibility Model, Source Attractiveness Model and Match-Up-Hypothesis: An Integrated Model. Journal of International Scientific Publications: Economy \& 
Business, 11(1), 1-15.

Soh, H., Reid, L. N., \& King, K. W. (2009). Measuring Trust in Advertising. Journal of Advertising, 38(2), 83-104. https://doi.org/10.2753/JOA0091-3367380206

Spears, N., \& Singh, S. N. (2004). Measuring Attitude toward the Brand and Purchase Intentions. Journal of Current Issues \& Research in Advertising, 26(2), 53-66. https://doi.org/10.1080/10641734.2004.10505164

Sundar, S. S., \& Kalyanaraman, S. (2004). Arousal, Memory, and Impression-Formation Effects of Animation Speed in Web Advertising. Journal of Advertising, 33(1), $7-17$. https://doi.org/10.1080/00913367.2004.10639152

Tangari, A. H., Folse, J. A. G., Burton, S., \& Kees, J. (2010). The Moderating Influence of Consumers' Temporal Orientation on the Framing of Societal Needs and Corporate Responses in Cause-Related Marketing Campaigns. Journal of Advertising, 39(2), 35-50. https://doi.org/10.2753/JOA0091-3367390203

Tran, V., \& Nguyen, H. (2020). Consumer Attitudes towards Beauty Bloggers and Paid Blog Advertisements on Purchase Intention in Vietnam. Management Science Letters, 10(5), 1017-1026. https://doi.org/10.5267/j.msl.2019.11.008

Trope, Y., \& Liberman, N. (2010). Construal-Level Theory of Psychological Distance. Psychological Review, 117(2), 440. https://doi.org/10.1037/a0018963

Verma, S. (2009). Do All Advertising Appeals Influence Consumer Purchase Decision: An Exploratory Study. Global Business Review, 10(1), 33-43. https://doi.org/10.1177/097215090801000102

Wiebe, J., Basil, D. Z., \& Runté, M. (2017). Psychological Distance and Perceived Consumer Effectiveness in a Cause-Related Marketing Context. International Review on Public and Nonprofit Marketing, 14(2), 197-215. https://doi.org/10.1007/s12208-016-0170-y

Xie, Q., \& Zhang, M. (2013). White or Tan? A Cross-Cultural Analysis of Skin Beauty Advertisements between China and the United States. Asian Journal of Communication, 23(5), 538-554. https://doi.org/10.1080/01292986.2012.756046

Zhenzhong, Z. H. U., Fu, L. I. U., \& Chen, H. A. (2020). Warmth or Competence? The Influence of Advertising Appeal and Self-Construal on Consumer-Brand Identification and Purchase Intention. Acta Psychologica Sinica, 52(3), 357-370. https://doi.org/10.3724/SP.J.1041.2020.00357

\section{Appendix A}

\section{Cosmetic Advertisement Stimuli}

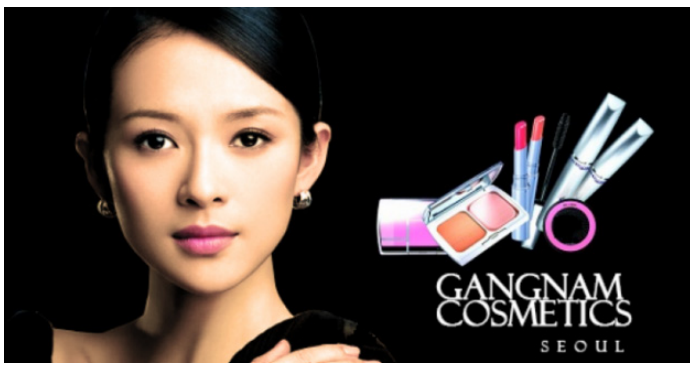

Asian Model x Asian brand

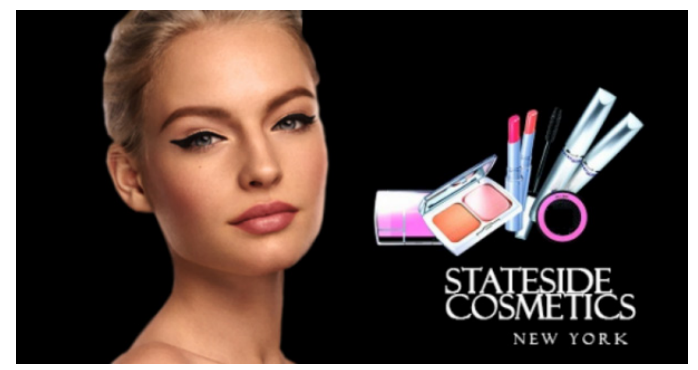

Caucasian Model x US brand

Note. Models are representative beauty models in their culture. Brand names bring brand origins to mind. The brand origins were switched for the other two experimental conditions.

\section{Copyrights}

Copyright for this article is retained by the author, with first publication rights granted to the journal.

This is an open-access article distributed under the terms and conditions of the Creative Commons Attribution license (http://creativecommons.org/licenses/by/4.0/). 